\title{
Role of ribosomal protein mutations in tumor development (Review)
}

\author{
KAVEH M. GOUDARZI ${ }^{1}$ and MIKAEL S. LINDSTRÖM ${ }^{2}$ \\ ${ }^{1}$ Department of Oncology-Pathology, Karolinska Institutet, Cancer Center Karolinska, CCK R8:05, \\ Karolinska University Hospital in Solna; ${ }^{2}$ Science for Life Laboratory, Division of Translational Medicine and \\ Chemical Biology, Department of Medical Biochemistry and Biophysics, Karolinska Institutet, Stockholm, Sweden
}

Received November 3, 2015; Accepted January 7, 2016

DOI: 10.3892/ijo.2016.3387

\begin{abstract}
Ribosomes are cellular machines essential for protein synthesis. The biogenesis of ribosomes is a highly complex and energy consuming process that initiates in the nucleolus. Recently, a series of studies applying whole-exome or whole-genome sequencing techniques have led to the discovery of ribosomal protein gene mutations in different cancer types. Mutations in ribosomal protein genes have for example been found in endometrial cancer (RPL22), T-cell acute lymphoblastic leukemia (RPL10, RPL5 and RPL11), chronic lymphocytic leukemia (RPS15), colorectal cancer (RPS20), and glioma (RPL5). Moreover, patients suffering from Diamond-Blackfan anemia, a bone marrow failure syndrome caused by mutant ribosomal proteins are also at higher risk for developing leukemia, or solid tumors. Different experimental models indicate potential mechanisms whereby ribosomal proteins may initiate cancer development. In particular, deregulation of the p53 tumor suppressor network and altered mRNA translation are mechanisms likely to be involved. We envisage that changes in expression and the occurrence of ribosomal protein gene mutations play important roles in cancer development. Ribosome biology constitutes a re-emerging vital area of basic and translational cancer research.
\end{abstract}

\section{Contents}

1. Introduction

2. The ribosome at a glance

3. Mutations and altered expression of ribosomal proteins in cancer

Correspondence to: Dr Mikael S. Lindström, Science for Life Laboratory, Division of Translational Medicine and Chemical Biology, Department of Medical Biochemistry and Biophysics, Karolinska Institutet, Box 1031, Stockholm SE-171 21, Sweden

E-mail: mikael.lindstrom@ki.se

Key words: cancer, ribosomal protein, ribosome biogenesis, p53, translation
4. Possible mechanisms whereby mutations in ribosomal proteins cause cancer

5. Ribosome biogenesis as a re-emerging target in the treatment of cancer

6. Conclusions and future perspective

\section{Introduction}

Cancer cells display a number of abnormal properties in order to maintain their unrestrained growth and proliferation (1). Ribosome biogenesis and protein synthesis are in this context critical cellular processes necessary for sustained cancer cell growth. Historically, ribosomes were considered to be relatively stable entities. However, with the discoveries of mutations affecting ribosomal protein (RP) genes in the DiamondBlackfan anemia (DBA) syndrome it became evident that mutant RPs may cause complex, variable, and viable phenotypes (2). Of note, DBA and other syndromes involving mutant ribosomal or nucleolar proteins are often associated with an increased life time risk of cancer (3). Recently, a number of studies using next generation sequencing technologies describe RP gene mutations also in cancers without a previous known history of bone marrow failure disorder. By applying wholeexome sequencing, RNA seq, or whole-genome sequencing, RP gene mutations have been detected in the genome of cancer cells, including from endometrial cancer, T-cell acute lymphoblastic leukemia (T-ALL), chronic lymphocytic leukemia (CLL), colorectal carcinomas, and high grade gliomas (4-7). The mechanisms underlying cancer development in the setting of a ribosome biogenesis defect remain poorly understood. In this review, the most recent studies are summarized and possible mechanisms by which mutant ribosomal proteins are linked to cancer development are discussed.

\section{The ribosome at a glance}

The basis of protein synthesis is the translation of messenger RNA (mRNA) to an amino acid sequence. Translation of mRNA is carried out by the ribosome, transfer RNA (tRNA), with the assistance of an army of different helper proteins. The intrinsic catalytic activity of ribosomes is thought to be dependent on ribosomal RNA (rRNA), that is involved in mRNA 
decoding and formation of peptide bonds. Certain chemical modifications on rRNA, including pseudo-uridylation and ribose methylation, are critical for maintaining proper rRNA structure and modulate the interactions between rRNA and proteins (8). The ribosome consists of two subunits, each of which is made up of ribosomal RNA (rRNA) and many RPs. Eukaryotes have $80 \mathrm{~S}$ ribosomes, consisting of the small (40S) and the large (60S) subunit. The large 60S subunit is composed of a $5 \mathrm{~S}$ rRNA, a $28 \mathrm{~S}$ rRNA, a $5.8 \mathrm{~S}$ subunit, and $\sim 46$ RPs. The small 40S subunit has an 18S rRNA and 233 RPs. Note that the 5S rRNA is transcribed by RNA polymerase III, while $28 \mathrm{~S}, 5.8 \mathrm{~S}$, and $18 \mathrm{~S}$ rRNAs are processed from a long precursor (pre-) rRNA transcribed by RNA polymerase I (9). The maturation of pre-rRNA occurs in the nucleolus involving both endo- and exonucleases that remove external and internal transcribed sequences. In the nucleolus the $45 \mathrm{~S}$ pre-RNA associates with RPs, ribonucleases, RNA helicases, small nucleolar RNPs and other accessory factors, to form 90S pre-ribosomes. During the maturation process, the $90 \mathrm{~S}$ pre-ribosome is separated into pre-40S and pre-60S subunits that are exported to the cytoplasm where maturation is completed (9). It should be noted that RPs are synthesized by pre-existing ribosomes in the cytoplasm and imported into the nucleus where majority of the RPs home into the nucleolus to assemble with rRNA, and majority of RPs are essential in ribosome biogenesis (10-12). Strikingly, RPs have high isoelectric points allowing them to interact with rRNAs, mRNAs, and tRNAs (13). The names of the RPs belonging to the large subunit include the prefix $L$ and the names of the RPs of the smaller subunit include the prefix S. A new universal nomenclature has been launched and we will provide both names at their first mentioning in the text (14).

Ribosome heterogeneity. Some cells have the potential to produce ribosomes with a different composition of RPs, and post-translational modifications, in response to changing extracellular demands. These adaptations have mostly been studied in bacteria, plants, and yeast but recently also in mammalian cells (15). There are a number of potential mechanisms leading to ribosome heterogeneity (16), although the nature of the heterogeneity is variable, from subtle changes in post-translational modification patterns to the loss of an RP. Duplicated RP genes exist in the genomes of some species such as plants. These extra RP genes are sometimes encoding for a variant protein (paralog) that may differ in amino acid sequence (17). Paralogs might have specific functional roles. For example, Rpl22 $2^{-/}$mice have only subtle phenotypes with no significant translation defects because in these mice there is a compensatory increase in Rpl22-likel (Rpl22ll) expression and incorporation into ribosomes (17). Importantly, knockdown of Rpl2211 impairs growth of cells lacking Rpl22 (17). Post-translational modifications of RPs (e.g. ubiquitination and phosphorylation) have been described and these may alter the functional properties of ribosomes (18). Another layer of ribosome heterogeneity may stem from differences in modification of the rRNA itself (8). RP genes also generate a large number of processed pseudogenes that are dispersed throughout the genome $(13,19)$. While the pseudogenes have been considered to be inactive there are studies indicating that they have the potential to produce functional coding RNA and protein (20).
Finally, it should be added that long non-coding RNAs are involved in regulating mRNA translation, a number of long non-coding RNAs associates with cytoplasmic ribosomes, and if we also include these regulatory levels, the complexity becomes even higher $(21,22)$. Taken together, there are a number of potential different mechanisms contributing to ribosome heterogeneity, and these are probably functionally relevant to both normal and cancer cells. One may suspect that certain mechanisms are dominant in cancer cells when compared to normal cells. It will be important to identify these differences as it might open up novel avenues for anticancer treatment.

A critical issue to keep in mind concerns the fate of preribosomes in the context of an RP mutation or deletion (23). It is known that the synthesis of ribosomes is a process regulated and balanced at multiple levels (24), and that RPs produced in excess are rapidly degraded in the nucleus $(25,26)$. Depletion of an individual RP in normal cultured cells often, but not always, results in a decrease in the total level of the other RPs belonging to the same ribosomal subunit, thus creating an unbalanced ribosome assembly pathway $(27,28)$. In the setting of an RP loss by deletion or an early truncating mutation one may therefore expect reduced numbers of ribosomes to be a common outcome. Normal and cancer cells may try to compensate a ribosome deficit by activation of pathways that boost ribosome production, e.g. the mTOR pathway (29). This situation may create a pressure to mutate components in the cell that normally restrains the pathway activity in question.

\section{Mutations and altered expression of ribosomal proteins in cancer}

Animal models with mutations in ribosomal protein genes increase cancer risk. Genes encoding RPs have been found mutated in some organisms including Drosophila and Zebrafish. Mutations in RP genes have also been found in humans. Minutes is a class of Drosophila mutants known for their short slender bristles (stiff hair) on the body, overall reduced body size and delayed metamorphosis (30). Minute genes often encode RPs thereby explaining certain aspects of the Minute phenotype, for example reduced body size. Paradoxically, decreased levels of a subset of Drosophila RPs result in overgrowth of specific tissues for example hypertrophied hematopoietic organs and melanotic tumors. The lymph glands are overgrown in Rps6 (eS6) mutant larvae, due to increased growth and proliferation of the lymph gland cells indicating that Rps6 has a tumor suppressive function $(31,32)$. Decreased levels of Rps6 in the prothoracic gland reduce the steroid hormone ecdysone delaying development, but tissues or organs continue to grow abnormally (33). As another prelude to what is now an emerging research field in cancer biology serves the finding of heterozygous loss-of-function mutations in several RPs that cause development of malignant peripheral nerve sheet tumors (MPNSTs) in zebrafish $(34,35)$. MPNSTs are sarcomas which emerge from peripheral nerves or from cells associated with the nerve sheath. Zebrafish carrying heterozygous mutations for 17 different RP genes are prone to MPNSTs. Noteworthy, MPNSTs also arise in zebrafish that have lost wild-type p53 function, and in line with this, p53 was not detected in cells derived from the tumors in the RP mutant 
Table I. Examples of ribosomal protein gene mutations in human tumors.

\begin{tabular}{|c|c|c|c|c|}
\hline $\mathrm{RP}$ & Tumor type & Mutation type & Examples & Ref. \\
\hline RPL5 (uL18) & $\begin{array}{l}\text { GBM, T-ALL, } \\
\text { lung-adenocarcinoma }\end{array}$ & $\begin{array}{l}\text { Missense, } \\
\text { insertions, } \\
\text { deletions }\end{array}$ & $\begin{array}{l}\text { p.Arg58LysfsX55, p.Asp59fs, } \\
\text { p.Gln63Arg, p.Arg179X, } \\
\text { p.Asn57fsX12,p.Arg54Cys, } \\
\text { p.Glu82Lys, p.Met212fs }\end{array}$ & $(4,5)$ \\
\hline RPL10 (uL16) & T-ALL & Missense & p.Arg98Ser, p.Arg98Cys & (4) \\
\hline RPL11(uL5) & T-ALL & Missense & p.Arg18Pro, p.Gly30fs & $(59)$ \\
\hline RPL22 (eL22) & $\begin{array}{l}\text { Gastric cancer, T-ALL, } \\
\text { endometrial, colorectal cancer }\end{array}$ & $\begin{array}{l}\text { Insertions, } \\
\text { deletions }\end{array}$ & $\begin{array}{l}\text { p.Lys 15ArgfsX5, } \\
\text { p.Lys16GlufsX9 }\end{array}$ & $(60-63)$ \\
\hline RPS15(uS19) & CLL & $\begin{array}{l}\text { Missense, } \\
\text { nonsense }\end{array}$ & $\begin{array}{l}\text { p.Gly105Ser, p.Ser111Phe } \\
\text { p.Pro131Ser, p.Gly132Ala }\end{array}$ & $(57,58)$ \\
\hline RPS20 (uS10) & Colorectal cancer & Insertion & p.Val50SerfsX23 & (6) \\
\hline
\end{tabular}

CLL, chronic lymphocytic leukemia; GBM, glioblastoma; RP, ribosomal protein; Ref, reference; T-ALL, T-cell acute lymphoblastic leukemia; fs, frameshift; X, stop.

fish (36). In contrast to Drosophila and Zebrafish, there are not many reports of increased tumor incidence in mice carrying mutations or deletions in RPs (for example Rps19, Rpl24 and Rps6). Although it is known that loss of a single Rpl22 allele accelerates development of thymic lymphoma in a mouse model of T-cell malignancy (37), and heterozygous Rpll1 mice are more prone to radiation-induced lymphomagenesis (38). A recent study describes an increased incidence of soft tissue sarcomas in mice lacking one allele of Rpl5 or Rps24 (39).

Ribosomopathies and cancer risk in humans. Congenital diseases found in humans that are linked to genetic defects in RPs or ribosome biogenesis factors are collectively known as the ribosomopathies (40-42). These include Dyskeratosis congenita (DKC), Diamond-Blackfan anemia (DBA), and Shwachman-Diamond syndrome (SDS) that constitute major inherited bone marrow failure syndromes (41). The ribosomopathies are characterized by a number of abnormalities including birth defects and anemia (41). DBA is a dominant autosomal bone marrow failure syndrome associated with mutations in RP genes including RPS19(eS19), RPS17(eS17), RPS24(eS24), RPL35A(eL33), RPS7(eS7), RPL5(uL18), RPL11(uL5), RPL26(uL24), RPL27(eL27), RPS10(eS10), RPS26(eS26), RPS27(eS27), RPL15(eL15), RPS28(eS28), RPL31(eL31) and RPS29(uS14) (2,3,43-45). Patients with DBA experience a block in erythroid progenitor cell division in the bone marrow coupled to an increased apoptosis (46). DBA patients have a 5-fold higher lifetime risk of cancer than the general population, specifically a 28 - to 36 -fold higher risk of developing AML, osteosarcoma, or colon cancer (3). Although a somatic mosaic disorder, and not congenital, RPS14(uS11) heterozygous loss is associated with $5 q$ - syndrome and the development of anemia (47). Patients with 5q- syndrome or SDS are at higher risk of developing AML (48-50). DKC is a syndrome characterized by premature aging and increase in cancer susceptibility. X-linked DKC, which has a more severe phenotype compared with the autosomal dominant form of $\mathrm{DKC}$, is caused by a mutation in $\mathrm{DKCl}$, which encodes dyskerin (51). Dyskerin is in part a nucleolus located protein associated with the snoRNPs involved in rRNA modification $(52,53)$. Patients with X-linked DKC are predisposed to AML, lymphoma, and a variety of solid tumors including squamous carcinoma (54). Note that both DKC and SDS have a higher risk of cancer development than DBA, especially the risk of leukemia, although some cohorts are rather small thus causing estimates with greater differences among the studies $(3,48,49,54,55)$. It should be emphasized that the main problem in DBA patients is related to acute effects from bone marrow failure or complications due to chronic blood transfusions and not cancer per se (56).

Cancer associated mutations in ribosomal protein genes. Genome-wide sequencing indicates that RP gene mutations are relatively frequent in some cancer types. $R P S 15(u S 19)$ mutations have been found in CLL and even more frequently in relapsed CLL (up to $19.5 \%$ of cases) $(57,58)$. Moreover, $\sim 10 \%$ of children with T-ALL have mutations in RP genes including RPL10(uL16), RPL5, RPL11, and RPL22 (4,59,60). In fact, $6.5 \%$ of T-ALL patients presented with an identical RPL10 Arg98Ser missense mutation (4) (Table I). A separate study in T-ALL patients identified a $10 \%$ incidence of heterozygous deletions in the region of chromosome 1p that harbors RPL22 (60), and a number of T-ALL cell lines and relapse cases had point mutations in RPL22 (60). In line with its potential role as tumor suppressor, $R P L 22$ is also mutated or have decreased expression in other cancers as well, including endometrial cancers, colorectal cancer, gastric cancer, breast carcinoma, and non-small cell lung carcinoma (7,61-63). Internal deletions and insertions resulting in early truncating frameshifts are most commonly seen, examples include RPL22 Lys15Arg and Lys16Glu (Table I). Truncating frameshift mutations in RPL5 have been detected in glioblastoma (5) and RPL5 (as well as RPL22) is identified as being mutated at a significant frequency in cancer (5). A closer look at TCGA 
data using the cBioportal website suggests that RPL10 and $R P L 22$ are deleted in cases of diffuse large B cell lymphoma, adrenocortical carcinoma, and sarcoma, and that RPL5 is mutated in a few cases of human MPNSTs (64), and potentially in other cancer types including endometrial carcinoma and lung adenocarcinoma. Genetic linkage analysis and exome sequencing led to the identification of a truncating germline mutation in RPS20(uS10) predisposing to colorectal cancer, which is interesting given the association of DBA with colon cancer, but a previous history of DBA appeared unlikely (6). Deep sequencing uncovered the existence of RPL39(eL39) mutations in cells from breast cancer lung metastatic lesions (65). A more complete picture of the relevant RPs in cancer will emerge from additional sequencing projects and from functional studies. One must also recall that possibly not all relevant RP mutations are detected since the mutations may be present in a small subpopulation of cells (66). Especially solid cancers often exhibit cell heterogeneity that may prevent the identification of specific mutations. Cell sorting in combination with single cell genome sequencing and single cell RNA-seq may provide more detailed information in the future.

Comparison of RP mutations in cancer and DBA. Are the DBA associated RP gene mutations different from the mutations that have been found in cancer? A cross-comparison of TCGA data with associated recent publications and information available in the DBA database (67), indicates that the mutations described to date usually are different but a few are actually in common. As with regard to RPL5, mutations Lys5fs, Val6fs, Arg35fs, Asn57fs and Asp59fs have been found in cancer and also the RPL5 point mutants Glu82Lys and Arg54Cys (Table I). There are a large number of DBA associated RPL5 mutants including Met1Arg and Arg58Lys. Most interestingly, two of the RPL5 mutations seen in DBA were also found in T-ALL namely Arg179X and Arg58LysfsX55. The region in RPL5 between Arg54 to Asp59 appears to be a 'hot spot' in both DBA and cancer. RPS15 frequently mutated in CLL is rarely so in DBA and the Met70Val DBA mutant has to date not been found in CLL. Also, the few RPL11 mutations in T-ALL described have so far not been observed in DBA. It will be important to investigate whether cancer associated mutations in RPs occur in the setting of an underlying ribosome biogenesis disorder.

Alterations in RP gene expression patterns. Changes in the expression levels (mRNA) of RPs in cancer is common (68), although in most studies it remain unclear to what extent changes in RP expression is merely a necessity to sustain rapid cancer cell growth. For example, increased expression of RPS2 was found in mouse hepatocellular carcinoma samples and in mouse livers after partial hepatectomy correlated with increased cell proliferation (69). Given the discovery of cancer associated genetic changes in RPs we must also consider changes in RP expression patterns as potentially relevant to cancer development. RPs have been found overexpressed in cancer, for example RPL15(eL15) and RPL19(eL19) in gastric cancer (70), and RPL7A(eL8), RPL19(eL19), RPL37(eL37), in prostate cancer $(71,72)$. RPs can also be expressed at reduced levels, e.g. RPL27(eL27), RPL37A(eL43) and RPL41(eL41) are downregulated in a subset of cell lines derived from nasopha- ryngeal carcinomas (73). Changes in the expression of RPs have in some cases been used to distinguish between normal and cancer cells, and these changes may even have prognostic or predictive values. For example, patients with prostate cancers that display low levels of RPL19 have better survival (72). Increased levels of RPS11(uS17) and RPS20(uS10) predicted poor survival of primary glioblastomas (74). In contrast, RPL15 expression status may serve as a prognostic marker in pancreatic ductal adenocarcinoma in that decreased expression was significantly associated with poor overall survival. A potential explanation could be related to an increased invasive capacity of the pancreatic cancer cells with a reduction in RPL15 (75). One study points out that levels of $R P L 13(\mathrm{eL13})$ correlated with clinical staging in gastric cancers (76). RPL36(eL36) has potential as a prognostic marker, its expression revealed better overall survival and was found to be an independent prognostic factor for overall survival in resected hepatocellular carcinoma (77). The aforementioned studies are just a few examples, and for more complete lists of cancer types with alterations in ribosomal proteins the reader is referred to recent reviews $(68,78)$. High resolution comparative genomic hybridization, RNA-seq, and analysis of DNA methylation patterns in promoter regions on a global scale, will shed further light on RPs and their alterations in cancer.

\section{Possible mechanisms whereby mutations in ribosomal proteins cause cancer}

Checkpoint activation - lessons from the mouse. The mechanism(s) by which RP mutations increase the risk of developing cancer remains an important unanswered question and several hypotheses have been proposed $(79,80)$. RP deficiency often causes complex phenotypes during development. These different phenotypes may arise from altered translation and/or from the effects of activation of cell stress responses including cell cycle arrest and apoptosis (81). This complexity is seen in a number of different mouse models. Rpl24(eL24) $)^{+-}$mice display a size decrease of approximately $20 \%$, white ventral midline spots, white hind feet, and kinked tails (82). Rpl29 $(e L 2)^{+/}$mice suffer from a global growth deficiency and shortened lifespan. Rpl38(eL38) ${ }^{+/-}$mice present with tissue-specific patterning defects due to the perturbation of a subset of Homeobox mRNAs (83). Given these pleiotropic phenotypes several mechanisms could also be involved in cancer development.

The best known response to ribosome biogenetic defects involves the tumor suppressor p53 that induces cell cycle arrest, senescence, apoptosis, or differentiation $(84,85)$. A number of mouse models confirm the involvement of p53 in mediating certain phenotypes. For example, deletion of only one allele of Rps 6 is enough to impair ribosome biogenesis, but the early embryonic lethality is due to activation of p53-dependent cell cycle arrest and apoptosis rather than to a general downregulation of protein synthesis (86). Furthermore, mutations in Rps19(eS19) and Rps20(uS10) in mice result in p53-dependent pigmentation defects (abnormal melanocyte proliferation), reduced body size, and anemia (87). Rpl22 deficient mice develop $\mathrm{T}$ lymphopenia by blocking $\alpha \beta$-T cell development in a p53-dependent manner $(37,88)$. Supporting observations also came from studies on the $5 \mathrm{q}$ - 


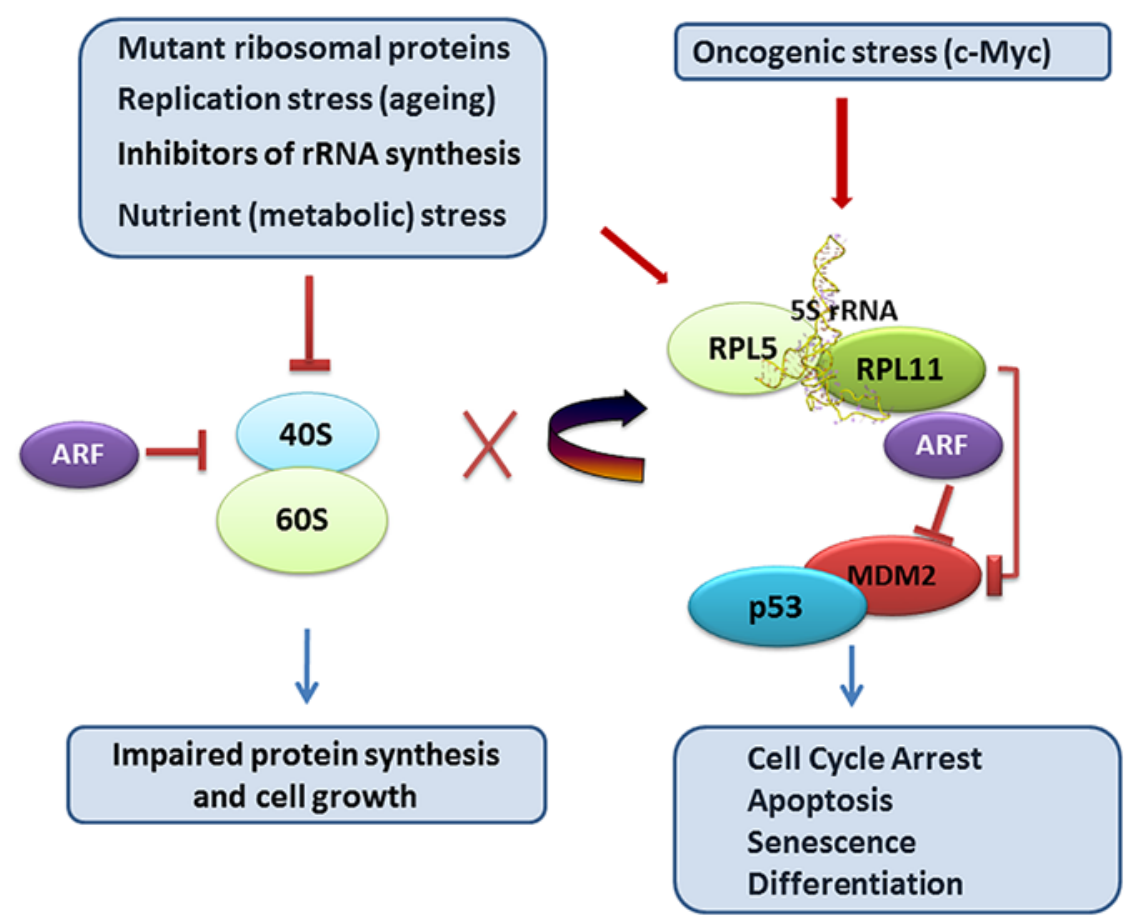

Figure 1. The 5S RNP complex (RPL5, RPL11 and 5S rRNA) regulates MDM2-p53 in response to cellular stress. Schematic overview showing the role of the 5S RNP in coupling disturbances in ribosome production that can be triggered by inhibitors of ribosomal RNA synthesis, mutations in essential ribosome components, nutrient stress, and replicative stress. Stabilization of p53 in response to illegtimate activation of oncogenes (c-Myc) relies partially on 5S RNP. Oncogenic stress also induces the ARF tumor suppressor that in turn inhibits ribosome biogenesis. Besides, ARF interacts with 5S RNP through RPL11/ MDM2 association. Not shown in the figure is the DNA damage sensing pathway through ATM/ATR kinases that is connected to ARF and p53.

syndrome. The haplo-insufficiency of RPS14 has a critical role in the development of the anemia that characterizes $5 \mathrm{q}$ syndrome (47). Bone marrow cells from a mouse model of $5 \mathrm{q}$ - syndrome shows elevated level of p53 and intercross with $\operatorname{Trp} 53^{-/}$mice rescued the macrocytic anemia and dysplasia phenotypes of the $5 q$ - mouse (89). For a more exhaustive list of the different mouse models having mutations in ribosomal protein genes we refer the reader to an informative overview by Terzian and Box (90).

5S RNP-p53 control mechanism. Activation of checkpoints for quality control of ribosome biogenesis is contributing to the disease manifestations among the ribosomopathies $(91,92)$. The hematopoietic phenotype in DBA patients is for example at least partially linked to the activation of p53 (93). What is the mechanism sensing ribosome dysfunction leading to p53 activation? It is now established that two RPs, namely RPL11 (uL5) and RPL5 (uL18), control p53-dependent cell cycle arrest, senescence or apoptosis in response to impaired ribosome biogenesis $(91,94,95)$. Loss of RPL5 or RPL11 also impairs ribosome biogenesis and stalls cell proliferation similar to other essential RPs $(27,95)$, but in the case of RPL11 or RPL5 there is no distinct cell cycle arrest (95). RPL11 and RPL5 regulate p53 as key components of the $5 \mathrm{~S}$ ribonucleoprotein particle (5S RNP), in which the 5S rRNA is essential as well (96-98). When ribosome biogenesis is blocked, the $5 \mathrm{~S}$ RNP pre-ribosomal complex is re-directed from assembly into 60S ribosomes to MDM2 E3 ligase inhibition (99-101) (Fig. 1). 5S RNP promotes cellular senescence in response to oncogenic or replicative stress, given that oncogenic stress accelerates rRNA transcription while replication stress delays
rRNA processing both causing imbalances in ribosome production (102) (Fig. 1). The 5S RNP complex also act as a sensor responsible for stimulating fatty acid oxidation in response to nutrient depletion (103), and sets the level of p53 activation by ARF (p14ARF, p19Arf), a protein induced by oncogenes (97). The ARF and RP-MDM2 interactions are distinct regulatory pathways and function in non-redundant manner to boost the p53 response to oncogenic c-Myc yet to some extent they rely on each other (104). ARF is a joker in the game and there are now a number of unresolved issues regarding the functional interplay between ARF and 5S RNP. 5S RNP (RPL11/RPL5/5S rRNA and MDM2) has now with these findings emerged as a critical coordinator of signaling pathways at the interface of cell growth and proliferation control. Intuitively, p53 would then be influenced by a number of other factors regulating $5 \mathrm{~S} \operatorname{RNP}(96,97)$.

Role of 5S RNP-p53 activation in DBA models and links to cancer. What is the functional relevance of the $5 \mathrm{~S}$ RNP-Mdm2-p53 pathway in DBA? Mice with reduced levels of Rps19, that display hallmarks of DBA and p53 activation, were crossed with Mdm2 $2^{\mathrm{C} 305 \mathrm{~F}}$ knock-in mice (105). The $\mathrm{Mdm} 2^{\mathrm{C} 305 \mathrm{~F}}$ mice have a disrupted 5S RNP-Mdm2 interaction (98) since the MDM2 $2^{\mathrm{C} 305 \mathrm{~F}}$ mutation causes a collapse of the MDM2 zinc finger, with subsequent loss of RPL5 and RPL11 binding (106-108). Upon induction of Rps19 deficiency, a disrupted 5S RNP-Mdm2 interaction by Mdm $2^{\mathrm{C} 305 \mathrm{~F}}$ was able to partially reverse the p53 response and improve the expansion of hematopoietic progenitors in vitro, and the anemia became less severe (105). One may then conclude that p53 activation through 5S RNP plays a role in DBA pathogenesis 
although it is not the only mechanism involved. The role of p53 is debated, and the anemia seen in zebrafish models of DBA is sometimes not ameliorated by the concomitant inactivation of p53 (109-113). Discrepancies among the studies may in part be explained by the fact that a more complete knockdown of an RP often results in severe p53-independent phenotypes, whereas a milder reduction generates a milder $\mathrm{p} 53$-dependent phenotype. We must also keep in mind that p63 and p73 in some settings may serve as a back-up for p53 functions (109).

Deregulation of the 5S RNP-MDM2-p53 pathway may have a functional role in the evolution of $5 \mathrm{q}$ - syndrome and DBA into malignancy such as leukemia. It is not far-fetched to suggest that the chronic growth inhibition caused by p53 in turn could select for mutations that promote unrestricted growth and overcomes p53 function (for example in RPL11, RPL5, MDM2 or TP53). Mutation in TP53 is considered a critical step in the progression of the 5q- syndrome to AML (114,115). An unresolved issue at the moment relates to the involvement of RPL11 and RPL5 since they are frequently mutated in DBA to begin with, and thus raising questions about the role of 5S RNP checkpoint in these patients. Indeed, heterozygous conditional loss of Rpll1 in adult mice triggered anemia similar to DBA patients (38), but the mice were more prone to radiation-induced lymphomagenesis, and also failed to induce p53 when treated with agents triggering ribosomal stress for example Actinomycin D (38). This is similar to MDM2 ${ }^{\mathrm{C} 305 \mathrm{~F}}$ knock-in mice that fail to mount a p53 response upon treatment with Actinomycin D (98). Most studies that describe an increased association of RPL11/RPL5 with MDM2 rely on Actinomycin D treatment or a severe reduction of an RP. DBA, however, develops on a heterozygous $\left(\mathrm{RP}^{+/}\right)$ background as a consequence of RP gene haploinsufficiency in hematopoiesis. Whether in the $R p l 11^{+/-}$cells there is sufficient residual RPL11 and/or RPL5 for the checkpoint to operate is not clear. There is a need to better understand the dynamics of RPL5/L11 binding to MDM2 in the context of reduced levels of one component of the 5S RNP complex and explore 5S RNP-independent mechanisms. For example, one such mechanism potentially relevant to cancer development is related to the AKT pathway. RP mutations in zebrafish suppress activity of the AKT pathway resulting in proteasomal degradation of p53 and by re-activating the AKT pathway stabilization of p53 was restored $(116,117)$. In support, RP-deficient zebrafish embryos (similar to RP haploinsufficient zebrafish tumor cells) exhibited normal p53 transcription, but reduced levels of p53 protein, and an impaired p53 response to DNA damage $(36,116,117)$. The role of AKT pathway in RPL11 deficient cells should therefore be explored. In summary, accumulating evidence from cell culture, mouse models and DBA patients indicate the importance of maintaining a normal 5S RNP regulation of p53, although a number of unresolved issues remains (38). Encouraging for the future is that the molecular anatomy of the MDM2-RPL11 complex have been resolved in greater detail and this allows for efforts to design tailor-made drugs (118). Such compounds may then either enhance or block the p53 response with potential benefits to cancer and DBA patients, respectively.

Alternative modes of 53 regulation. In addition to the 5S RNP complex, other possible signaling molecules are thought to be activated in ribosome deficient cells and that may converge on p53 to increase its activity. ATR and ATM kinases are key components of the replication stress and DNA-damage checkpoints contributing to $\mathrm{p} 53$ activation. The ATR-Chk1 pathway was implicated in cell cycle arrest induced by inhibition of rRNA synthesis using Actinomycin D although in the absence of DNA damage (119), and was also found activated in RPS19deficient human cells (120). Increased levels of DNA damage response markers including $\gamma \mathrm{H} 2 \mathrm{AX}$ were detected in U2OS cancer cells depleted of RPS9 (uS4) (27). Another potential mechanism could be related to maintenance of proper nucleolar structure and genome stability. The nucleolus plays an important role in the spatial organization of certain heterochromatin enriched chromosome domains (121). Disruption of the heterochromatin architecture surrounding nucleoli has been described in cells depleted of RPs indicating there is a fine balance between ribosome biogenesis and chromatin organization (122). Altered organization of heterochromatin including silent rDNA may predispose cells to genome instability and DNA damage (123).

Autophagy is probably a relatively common cellular response to loss of an RP. Autophagy could be dependent or independent of mTOR and p53 in a cell type-specific manner $(117,124)$. There are other p53-independent effects seen in cells with defects in ribosome biogenesis for example directed degradation of the E2F-1 transcription factor. p53-independent ribosome biogenesis effects have been reviewed (84,125-127). In essence it is clear that activation of specific cell protective mechanisms appears as a common response to a shortage in ribosomes.

Alterations in mRNA translation. Other potential mechanisms that may play a role in cancers with RP mutations and in the ribosomopathies are related to the hypothesis that defective maturation of ribosomal subunits could delay translation of certain mRNAs or that malfunction of accumulated ribosomal precursors may cause aberrant translation (reduced fidelity). It may involve differential translation of specific mRNA transcripts or the use of alternative translation initiation sites. Both quantitative variations in actual ribosome numbers and qualitative alterations such as lack of rRNA modifications of the ribosomes have been reported. A first example is $\mathrm{X}$-linked DKC, caused by a mutation in $D K C 1$, which encodes dyskerin (51). Nucleolar dyskerin associates with a specific group of snoRNPs known as H/ACA, which function in the pseudo-uridylation of rRNAs, but mutant DKC1 alters the rRNA pseudo-uridylation pattern of ribosomes reducing translation of some mRNAs (53). A second example is fibrillarin, a nucleolar rRNA methyl-transferase (52). p53 represses fibrillarin by direct protein-protein interaction and high levels of fibrillarin are accompanied by abnormal rRNA methylation patterns and impaired translational fidelity (128). In this setting, p53 acts as a surveyor of protein synthesis by its ability to regulate ribosome activity (128). The translation fidelity model has gathered additional experimental evidence. The RPL10 Arg98Ser mutant, the most commonly identified ribosomal mutation in acute T-ALL, was functionally evaluated in yeast (129). The mutation leads to a failure to produce $60 \mathrm{~S}$ followed by degradation of the defective ribosomes (129). The 60S subunit shortage puts pressure on cells to select 
for suppressors of the ribosome biogenesis defect, allowing the yeast cells to boost ribosome production to sustain cell proliferation (129). However, the consequence of this bypass is synthesis of defective ribosomes that wreak havoc in the mRNA translation process (129). Whether similar mechanisms exist in humans and how they function remains to be investigated. It is interesting to note that some of the RPs mutated in cancer including RPL5, RPL10 and RPS20 are known to bind directly to mRNAs, moreover, two of them RPL5 and RPL10, have a preferential association with monosomes reflecting ribosome heterogeneity (15).

Another possibility to explain how defects in the synthesis or function of the ribosomes could affect the pattern of translated mRNAs and possibly lead to cell transformation involves changes in the mRNA translation patterns. A study in mice revealed a selective reduction in the translation of Hox mRNAs following deletion of Rpl38 (83), and as another example serves the transcription factor GATA1 being critical for normal erythropoiesis. Its mRNA is inefficiently translated in DBA patients (130), while mutated in other DBA cases (131). In an interesting twist, GATA1 binding to RP gene promoters is important to sustain high levels of RPs in erythroid cells (132). A more specific hypothesis that has been discussed is that a ribosome deficit may impact on the translation patterns favoring the synthesis of oncogenic proteins by altering the ratio between translation initiation and elongation (133). Related to this is the hypothesis that a reduced number of ribosomes may cause a selective reduced translation of mRNAs that are difficult to translate while other mRNA could become increasingly translated. Indeed, a decrease in p53 mRNA translation has been suspected to be of relevance during tumor development (36). Reduced mRNA translation may also result in a shortage of DNA replication and repair factors as well as histones that in turn may result in genome instability. Ribosome profiling will in the contexts of pre-existing ribosome biogenesis or mature ribosome defects become an essential tool to study changes in translation patterns and finding novel targets for intervention (134).

Gain or loss of extra-ribosomal functions in cancer. RPs are often regulated in surprisingly sophisticated manner and several RPs possess extra-ribosomal functions. In addition to their roles in ribosome biogenesis and mature ribosome function, some RPs are involved in DNA repair, transcription, RNA processing and apoptosis (82,135-137). A few of these extra ribosomal functions are relevant to discuss in the context of cancer development. To begin with, a number of RPs may affect cell growth to promote cancer cell proliferation. For example, overexpression of RPS3A leads to the transformation of mouse NIH3T3 cells and the formation of tumors in nude mice (138). Another example is RPS13 (uS15) that promotes gastric cancer growth by decreasing levels of p27Kip1 (139). Upregulation of RPS13 accelerated the growth, enhanced in vitro colony formation and soft agar growth, and promoted in vivo tumor formation whereas downregulation of RPS13 in gastric cancer cells led to $\mathrm{G}_{1}$ arrest (139). RPS13 as well as RPL23 (uL14) may also suppress drug-induced apoptosis of gastric cancer cells (140). Growth inhibitory functions of RPs have been described as well. The most obvious examples are perhaps RPL5 and RPL11 that when overexpressed inhibit MDM2 (141). Many other RPs including RPS15 also bind MDM2 and may impact on the p53 response $(57,142)$. Decreased levels of RPL41 (eL41) led to anchorage-independent growth of NIH3T3 cells in soft agar and increased tumor growth in mice (143), while in contrast the enforced expression of RPL41 triggered cell cycle arrest and sensitized cancer cells to cisplatin (143). One must emphasize that cells are sensitive to enforced disturbances in the balance of RPs, and even that certain tags when fused to RPs including GFP, HA or FLAG may prevent or interfere with an RPs assembly into ribosomes (144). Therefore, anti-proliferative effects stemming from the ectopic overexpression of RPs may be indirect.

There are more elaborate mechanisms relevant to bring up in the context of the cancer-associated mutations occurring in RPL5, RPL22 and RPL10. For example, RPL10 has been linked to regulation of the oncogenic transcription factor JUN and other non-ribosome related proteins (145), and these functions could potentially be altered by the RPL10-Arg98Ser mutant with implications for cancer development. Another intriguing example is the inactivation of RPL22 that enhances transformation potential through induction of the Lin28B stemness factor (60). The mechanism whereby a deficiency in RPL22 induces Lin28B is not known. RPL22 is an RNA binding protein (146) but it also associates with chromatin and is involved in gene repression through complex formation with linker histone H1 (147). The possibility that RPL22 has specific functions in gene regulation on a transcriptional level must therefore be taken into consideration. This finding, together with the unusual mode of $\mathrm{Rpl} 22$ regulation in mice (17) and a number of links to p53 regulation $(37,88,148,149)$ suggest that RPL22 is a very interesting candidate for use in diagnostic, prognostic and therapeutic applications related to cancer.

\section{Ribosome biogenesis as a re-emerging target in the treatment of cancer}

The rate of cell growth is often in proportion to the numbers of new ribosomes made $(150,151)$. It may therefore not come as a surprise to learn that many anticancer drugs interfere with RNA pol I transcription or ribosomal RNA (rRNA) metabolism leading to preferential targeting of dividing cancer cells. Inhibition of ribosome biogenesis by chemotherapeutic drugs may contribute significantly to the efficacy of therapeutic regimens. Ribosome biogenesis has the potential to be more effectively exploited as a target in anticancer therapy given that it is one of the major biosynthetic activities in a cancer cell. RNA Pol I, the multiprotein complex that synthesizes rRNA, is very active in most cancer cells (152). Selective inhibitors of RNA Pol I may therefore offer a general therapeutic strategy to block cancer cell proliferation and small molecule compounds that specifically inhibit rDNA transcription have been developed by academic teams and biotech companies (153). One compound CX-3543, target rRNA synthesis by disrupting G-quadruplex DNA structures in the G-rich region of the rRNA repeat, thereby altering the binding of proteins required for rRNA transcription (154). A second compound, CX-5461 is an inhibitor of RNA pol I transcription that works by specifically impairing the binding of SL1/TIF-1B to the rDNA promoter thereby inhibiting the initiation of rRNA synthesis (155). This latter compound selectively inhibits 
Pol I-driven transcription relative to Pol II-driven transcription, DNA replication, and translation. CX-5461 selectively kills B-lymphoma cells in vivo by induction of p53-dependent apoptotic signaling (156). The small molecule and acridine derivative, BMH-21 was found to have potent antitumorigenic activity (157). BMH-21 intercalates into GC-rich sequences in rDNA genes, and represses RNA Pol I transcription (158). A related compound, the acridine derivative CID-765471, inhibits rDNA transcription and activates p53 through 5S RNP also in the absence of detectable DNA damage (159). The mechanism involved in the case of CID-765471 is similar to BMH-21 in that there is a selective degradation of the RPA194 subunit of RNA polymerase I. Degradation of RPA194 could be a common event in the case of nucleolar disruption by nongenotoxic acridines, however it is not a general feature of all rDNA intercalating compounds (159). The type of anticancer activity and non-genotoxic activation of p53 represented by these different compounds mentioned holds great promise in future anticancer therapy, but whether selective targeting of ribosome biogenesis will be of broad clinical value in anticancer treatment remain to be seen.

One may of course also consider other targets in the ribosome biogenesis machinery including ribosomal proteins themselves. RPS2 (uS5) was reported to be a novel therapeutic target in prostate cancer whereas knock down of RPS2 expression had little effect on normal cells (160), in similar ways knock down of RPL19 (eL19) abrogated the aggressive phenotype of human prostate cancer (161). Depletion of the primary rRNA binding RPS9 (uS4) induced p53-dependent cell cycle arrest and differentiation in glioma cells (27). As an interesting example, RPL39 was found to be a protein that affects breast cancer stem cell self-renewal through a nonbiased screening approach (65). Depletion of RPL39 reduced tumor growth and metastasis associated with fewer cancer stem cells with a potential link to the nitric oxide synthase pathway (65). Clearly, additional studies targeting ribosomal components in various in vivo cancer models are warranted. Finally, one may envisage that acquired ribosome defects, or 'cancer-specific' ribosomes, may become novel targets in anticancer therapy (162).

\section{Conclusions and future perspective}

From studies on the ribosomopathies it is clear that impaired ribosome biogenesis is to be considered a risk factor for cancer initiation. Remarkably, distinct and recurrent mutations in genes encoding for ribosomal proteins (RPs) have recently been implicated in cancer development in patients without a previous known history of a ribosomopathy. This has been a wake-up call in the tumor biology field and one may compare this with the parallel and equally remarkable discovery of histone H3.3 mutations in pediatric gliomas (163). The role of RPs in cancer is a complex issue and while some exert a direct effect on proto-oncogenes and tumor suppressor genes, e.g. p53, it is possible that mutations in other RPs may have general effects on mRNA translation. The trend evident from the assembled sequencing data suggests that RP mutations or changes in the expression patterns of RPs could be functionally relevant in a large number of cancer types and cases. A more complete picture of the relevant RPs in cancer is due to emerge from additional cancer genome analysis projects and functional studies.

\section{Acknowledgements}

This work was supported by Karolinska Institutet and the Swedish Research Council (VR-MH project K2012-99X-21969-01-3) to M.L.

\section{References}

1. Hanahan D and Weinberg RA: Hallmarks of cancer: The next generation. Cell 144: 646-674, 2011.

2. Draptchinskaia N, Gustavsson P, Andersson B, Pettersson M, Willig TN, Dianzani I, Ball S, Tchernia G, Klar J, Matsson H, et al: The gene encoding ribosomal protein S19 is mutated in Diamond-Blackfan anaemia. Nat Genet 21: 169-175, 1999.

3. Vlachos A, Rosenberg PS, Atsidaftos E, Alter BP and Lipton JM: Incidence of neoplasia in Diamond Blackfan anemia: A report from the Diamond Blackfan Anemia Registry. Blood 119: 3815-3819, 2012.

4. De Keersmaecker K, Atak ZK, Li N, Vicente C, Patchett S, Girardi T, Gianfelici V, Geerdens E, Clappier E, Porcu M, et al: Exome sequencing identifies mutation in CNOT3 and ribosomal genes RPL5 and RPL10 in T-cell acute lymphoblastic leukemia. Nat Genet 45: 186-190, 2013.

5. Lawrence MS, Stojanov P, Mermel CH, Robinson JT, Garraway LA, Golub TR, Meyerson M, Gabriel SB, Lander ES and Getz G: Discovery and saturation analysis of cancer genes across 21 tumour types. Nature 505: 495-501, 2014.

6. Nieminen TT, O'Donohue MF, Wu Y, Lohi H, Scherer SW, Paterson AD, Ellonen P, Abdel-Rahman WM, Valo S, Mecklin JP, et al: Germline mutation of RPS20, encoding a ribosomal protein, causes predisposition to hereditary nonpolyposis colorectal carcinoma without DNA mismatch repair deficiency. Gastroenterology 147: 595-598.e5, 2014.

7. Novetsky AP, Zighelboim I, Thompson DM Jr, Powell MA, Mutch DG and Goodfellow PJ: Frequent mutations in the RPL22 gene and its clinical and functional implications. Gynecol Oncol 128: 470-474, 2013.

8. Sharma S and Lafontaine DL: 'View From A Bridge': A new perspective on eukaryotic rRNA base modification. Trends Biochem Sci 40: 560-575, 2015.

9. Boisvert FM, van Koningsbruggen S, Navascués J and Lamond AI: The multifunctional nucleolus. Nat Rev Mol Cell Biol 8: 574-585, 2007.

10. Ferreira-Cerca S, Pöll G, Gleizes PE, Tschochner H and Milkereit P: Roles of eukaryotic ribosomal proteins in maturation and transport of pre-18S rRNA and ribosome function. Mol Cell 20: 263-275, 2005.

11. Ferreira-Cerca S, Pöll G, Kühn H, Neueder A, Jakob S, Tschochner $\mathrm{H}$ and Milkereit P: Analysis of the in vivo assembly pathway of eukaryotic 40S ribosomal proteins. Mol Cell 28: 446-457, 2007.

12. Robledo S, Idol RA, Crimmins DL, Ladenson JH, Mason PJ and Bessler M: The role of human ribosomal proteins in the maturation of rRNA and ribosome production. RNA 14: 1918-1929, 2008.

13. Kenmochi N, Kawaguchi T, Rozen S, Davis E, Goodman N, Hudson TJ, Tanaka T and Page DC: A map of 75 human ribosomal protein genes. Genome Res 8: 509-523, 1998.

14. Ban N, Beckmann R, Cate JH, Dinman JD, Dragon F, Ellis SR, Lafontaine DL, Lindahl L, Liljas A, Lipton JM, et al: A new system for naming ribosomal proteins. Curr Opin Struct Biol 24: 165-169, 2014.

15. Slavov N, Semrau S, Airoldi E, Budnik B and van Oudenaarden A: Differential stoichiometry among core ribosomal proteins. Cell Rep 13: 865-873, 2015.

16. Gilbert WV: Functional specialization of ribosomes? Trends Biochem Sci 36: 127-132, 2011.

17. O'Leary MN, Schreiber KH, Zhang Y, Duc AC, Rao S, Hale JS, Academia EC, Shah SR, Morton JF, Holstein CA, et al: The ribosomal protein Rpl22 controls ribosome composition by directly repressing expression of its own paralog, Rp12211. PLoS Genet 9: e1003708, 2013. 
18. Xirodimas DP, Sundqvist A, Nakamura A, Shen L, Botting C and Hay RT: Ribosomal proteins are targets for the NEDD8 pathway. EMBO Rep 9: 280-286, 2008

19. Ishii K, Washio T, Uechi T, Yoshihama M, Kenmochi N and Tomita M: Characteristics and clustering of human ribosomal protein genes. BMC Genomics 7: 37, 2006.

20. Branca RM, Orre LM, Johansson HJ, Granholm V, Huss M Pérez-Bercoff Å, Forshed J, Käll L and Lehtiö J: HiRIEF LC-MS enables deep proteome coverage and unbiased proteogenomics. Nat Meth 11: 59-62, 2014

21. Lafontaine DL: Noncoding RNAs in eukaryotic ribosome biogenesis and function. Nat Struct Mol Biol 22: 11-19, 2015.

22. van Heesch S, van Iterson M, Jacobi J, Boymans S, Essers PB, de Bruijn E, Hao W, MacInnes AW, Cuppen E and Simonis M: Extensive localization of long noncoding RNAs to the cytosol and mono- and polyribosomal complexes. Genome Biol 15: R6, 2014.

23. Lafontaine DL: A 'garbage can' for ribosomes: How eukaryotes degrade their ribosomes. Trends Biochem Sci 35: 267-277, 2010.

24. Perry RP: Balanced production of ribosomal proteins. Gene 401 1-3, 2007.

25. Lam YW, Lamond AI, Mann M and Andersen JS: Analysis of nucleolar protein dynamics reveals the nuclear degradation of ribosomal proteins. Curr Biol 17: 749-760, 2007.

26. Warner JR: In the absence of ribosomal RNA synthesis, the ribosomal proteins of HeLa cells are synthesized normally and degraded rapidly. J Mol Biol 115: 315-333, 1977.

27. Lindström MS and Nistér M: Silencing of ribosomal protein S9 elicits a multitude of cellular responses inhibiting the growth of cancer cells subsequent to p53 activation. PLoS One 5: e9578, 2010.

28. Badhai J, Fröjmark AS, Razzaghian HR, Davey E, Schuster J and Dahl N: Posttranscriptional down-regulation of small ribosomal subunit proteins correlates with reduction of $18 \mathrm{~S}$ rRNA in RPS19 deficiency. FEBS Lett 583: 2049-2053, 2009.

29. Payne EM, Virgilio M, Narla A, Sun H, Levine M, Paw BH, Berliner N, Look AT, Ebert BL and Khanna-Gupta A: L-Leucine improves the anemia and developmental defects associated with Diamond-Blackfan anemia and $\operatorname{del}(5 \mathrm{q})$ MDS by activating the mTOR pathway. Blood 120: 2214-2224, 2012

30. Lambertsson A: The minute genes in Drosophila and their molecular functions. Adv Genet 38: 69-134, 1998.

31. Stewart MJ and Denell R: Mutations in the Drosophila gene encoding ribosomal protein S6 cause tissue overgrowth. Mol Cell Biol 13: 2524-2535, 1993.

32. Watson KL, Konrad KD, Woods DF and Bryant PJ: Drosophila homolog of the human S6 ribosomal protein is required for tumor suppression in the hematopoietic system. Proc Natl Acad Sci USA 89: 11302-11306, 1992.

33. Lin JI, Mitchell NC, Kalcina M, Tchoubrieva E, Stewart MJ Marygold SJ, Walker CD, Thomas G, Leevers SJ, Pearson RB, et al: Drosophila ribosomal protein mutants control tissue growth non-autonomously via effects on the prothoracic gland and ecdysone. PLoS Genet 7: e1002408, 2011.

34. Amsterdam A, Sadler KC, Lai K, Farrington S, Bronson RT, Lees JA and Hopkins N: Many ribosomal protein genes are cancer genes in zebrafish. PLoS Biol 2: E139, 2004

35. Lai K, Amsterdam A, Farrington S, Bronson RT, Hopkins N and Lees JA: Many ribosomal protein mutations are associated with growth impairment and tumor predisposition in zebrafish. Dev Dyn 238: 76-85, 2009.

36. MacInnes AW, Amsterdam A, Whittaker CA, Hopkins N and Lees JA: Loss of p53 synthesis in zebrafish tumors with ribosomal protein gene mutations. Proc Natl Acad Sci USA 105: 10408-10413, 2008 .

37. Stadanlick JE, Zhang Z, Lee SY, Hemann M, Biery M, Carleton MO, Zambetti GP, Anderson SJ, Oravecz T and Wiest DL: Developmental arrest of T cells in Rpl22-deficient mice is dependent upon multiple p53 effectors. J Immunol 187: 664-675, 2011.

38. Morgado-Palacin L, Varetti G, Llanos S, Gómez-López G, Martinez D and Serrano M: Partial Loss of Rpl11 in Adult mice recapitulates diamond-blackfan anemia and promotes lymphomagenesis. Cell Rep 13: 712-722, 2015.

39. Kazerounian S, Ciarlini PD, Yuan D, Ghazvinian R, Alberich-Jorda M, Joshi M, Zhang H, Beggs AH and Gazda HT: Development of soft tissue sarcomas in ribosomal proteins L5 and S24 heterozygous mice. J Cancer 7: 32-36, 2016.

40. McCann KL and Baserga SJ: Genetics. Mysterious ribosomopathies. Science 341: 849-850, 2013.
41. Narla A and Ebert BL: Ribosomopathies: Human disorders of ribosome dysfunction. Blood 115: 3196-3205, 2010

42. Freed EF, Bleichert F, Dutca LM and Baserga SJ: When ribosomes go bad: Diseases of ribosome biogenesis. Mol Biosyst 6: 481-493, 2010

43. Choesmel V, Fribourg S, Aguissa-Touré AH, Pinaud N, Legrand P, Gazda HT and Gleizes PE: Mutation of ribosomal protein RPS24 in Diamond-Blackfan anemia results in a ribosome biogenesis disorder. Hum Mol Genet 17: 1253-1263, 2008.

44. Cmejla R, Cmejlova J, Handrkova H, Petrak J, Petrtylova K, Mihal V, Stary J, Cerna Z, Jabali Y and Pospisilova D: Identification of mutations in the ribosomal protein L5 (RPL5) and ribosomal protein L11 (RPL11) genes in Czech patients with Diamond-Blackfan anemia. Hum Mutat 30: 321-327, 2009.

45. Farrar JE, Nater M, Caywood E, McDevitt MA, Kowalski J, Takemoto CM, Talbot CC Jr, Meltzer P, Esposito D, Beggs AH, et al: Abnormalities of the large ribosomal subunit protein, Rpl35a, in Diamond-Blackfan anemia. Blood 112: 1582-1592, 2008.

46. Flygare J and Karlsson S: Diamond-Blackfan anemia: Erythropoiesis lost in translation. Blood 109: 3152-3154, 2007.

47. Ebert BL, Pretz J, Bosco J, Chang CY, Tamayo P, Galili N, Raza A, Root DE, Attar E, Ellis SR, et al: Identification of RPS14 as a $5 \mathrm{q}-$ syndrome gene by RNA interference screen. Nature 451: 335-339, 2008

48. Alter BP, Giri N, Savage SA, Peters JA, Loud JT, Leathwood L, Carr AG, Greene MH and Rosenberg PS: Malignancies and survival patterns in the National Cancer Institute inherited bone marrow failure syndromes cohort study. Br J Haematol 150: 179-188, 2010

49. Majeed F, Jadko S, Freedman MH and Dror Y: Mutation analysis of SBDS in pediatric acute myeloblastic leukemia. Pediatr Blood Cancer 45: 920-924, 2005.

50. Maserati E, Pressato B, Valli R, Minelli A, Sainati L, Patitucci F, Marletta C, Mastronuzzi A, Poli F, Lo Curto F, et al: The route to development of myelodysplastic syndrome/acute myeloid leukaemia in Shwachman-Diamond syndrome: The role of ageing, karyotype instability, and acquired chromosome anomalies. Br J Haematol 145: 190-197, 2009.

51. Heiss NS, Knight SW, Vulliamy TJ, Klauck SM, Wiemann S, Mason PJ, Poustka A and Dokal I: X-linked dyskeratosis congenita is caused by mutations in a highly conserved gene with putative nucleolar functions. Nat Genet 19: 32-38, 1998.

52. Ge J, Rudnick DA, He J, Crimmins DL, Ladenson JH, Bessler M and Mason PJ: Dyskerin ablation in mouse liver inhibits rRNA processing and cell division. Mol Cell Biol 30: 413-422, 2010

53. Jack K, Bellodi C, Landry DM, Niederer RO, Meskauskas A, Musalgaonkar S, Kopmar N, Krasnykh O, Dean AM, Thompson SR, et al: rRNA pseudouridylation defects affect ribosomal ligand binding and translational fidelity from yeast to human cells. Mol Cell 44: 660-666, 2011.

54. Alter BP, Giri N, Savage SA and Rosenberg PS: Cancer in dyskeratosis congenita. Blood 113: 6549-6557, 2009.

55. Donadieu J, Leblanc T, Bader Meunier B, Barkaoui M, Fenneteau O, Bertrand Y, Maier-Redelsperger M, Micheau M, Stephan JL, Phillipe N, et al; French Severe Chronic Neutropenia Study Group; Experience of the French Severe Chronic Neutropenia Study Group: Analysis of risk factors for myelodysplasias, leukemias and death from infection among patients with congenital neutropenia. Haematologica 90: 45-53, 2005.

56. Danilova N and Gazda HT: Ribosomopathies: How a common root can cause a tree of pathologies. Dis Model Mech 8: 1013-1026, 2015

57. Ljungström V, Cortese D, Young E, Pandzic T, Mansouri L, Plevova K, Ntoufa S, Baliakas P, Clifford R, Sutton LA, et al: Whole-exome sequencing in relapsing chronic lymphocytic leukemia: Clinical impact of recurrent RPS15 mutations. Blood Dec 16, 2015 (Epub ahead of print).

58. Landau DA, Tausch E, Taylor-Weiner AN, Stewart C, Reiter JG Bahlo J, Kluth S, Bozic I, Lawrence M, Böttcher S, et al: Mutations driving CLL and their evolution in progression and relapse. Nature 526: 525-530, 2015.

59. Tzoneva G, Perez-Garcia A, Carpenter Z, Khiabanian H, Tosello V, Allegretta M, Paietta E, Racevskis J, Rowe JM, Tallman MS, et al: Activating mutations in the NT5C2 nucleotidase gene drive chemotherapy resistance in relapsed ALL. Nat Med 19: 368-371, 2013.

60. Rao S, Lee SY, Gutierrez A, Perrigoue J, Thapa RJ, Tu Z, Jeffers JR, Rhodes M, Anderson S, Oravecz T, et al: Inactivation of ribosomal protein L22 promotes transformation by induction of the stemness factor, Lin28B. Blood 120: 3764-3773, 2012. 
61. Ferreira AM, Tuominen I, van Dijk-Bos K, Sanjabi B, van der Sluis $T$, van der Zee AG, Hollema H, Zazula M, Sijmons RH, Aaltonen LA, et al: High frequency of RPL22 mutations in microsatellite-unstable colorectal and endometrial tumours. Hum Mutat 35: 1442-1445, 2014.

62. Nagarajan N, Bertrand D, Hillmer AM, Zang ZJ, Yao F, Jacques PÉ, Teo AS, Cutcutache I, Zhang Z, Lee WH, et al: Whole-genome reconstruction and mutational signatures in gastric cancer. Genome Biol 13: R115, 2012.

63. Yang M, Sun H, Wang H, Zhang S, Yu X and Zhang L: Downregulation of ribosomal protein L22 in non-small cell lung cancer. Med Oncol 30: 646, 2013.

64. Lee W, Teckie S, Wiesner T, Ran L, Prieto Granada CN, Lin M, Zhu S, Cao Z, Liang Y, Sboner A, et al: PRC2 is recurrently inactivated through EED or SUZ12 loss in malignant peripheral nerve sheath tumors. Nat Genet 46: 1227-1232, 2014.

65. Dave B, Granados-Principal S, Zhu R, Benz S, Rabizadeh S, Soon-Shiong P, Yu KD, Shao Z, Li X, Gilcrease M, et al: Targeting RPL39 and MLF2 reduces tumor initiation and metastasis in breast cancer by inhibiting nitric oxide synthase signaling. Proc Natl Acad Sci USA 111: 8838-8843, 2014.

66. Nakagawa H, Wardell CP, Furuta M, Taniguchi $\mathrm{H}$ and Fujimoto A: Cancer whole-genome sequencing: Present and future. Oncogene 34: 5943-5950, 2015.

67. Boria I, Quarello P, Avondo F, Garelli E, Aspesi A, Carando A, Campagnoli MF, Dianzani I and Ramenghi U: A new database for ribosomal protein genes which are mutated in DiamondBlackfan Anemia. Hum Mutat 29: E263-E270, 2008.

68. Wang W, Nag S, Zhang X, Wang MH, Wang H, Zhou J and Zhang R: Ribosomal proteins and human diseases: pathogenesis, molecular mechanisms, and therapeutic implications. Med Res Rev 35: 225-285, 2014.

69. Kowalczyk P, Woszczyński M and Ostrowski J: Increased expression of ribosomal protein S2 in liver tumors, posthepactomized livers, and proliferating hepatocytes in vitro. Acta Biochim Pol 49: 615-624, 2002.

70. Wang H, Zhao LN, Li KZ, Ling R, Li XJ and Wang L: Overexpression of ribosomal protein L15 is associated with cell proliferation in gastric cancer. BMC Cancer 6: 91, 2006.

71. Vaarala MH, Porvari KS, Kyllönen AP, Mustonen MV, Lukkarinen O and Vihko PT: Several genes encoding ribosomal proteins are over-expressed in prostate-cancer cell lines: Confirmation of L7a and L37 over-expression in prostate-cancer tissue samples. Int J Cancer 78: 27-32, 1998.

72. Bee A, Ke Y, Forootan S, Lin K, Beesley C, Forrest SE and Foster CS: Ribosomal protein 119 is a prognostic marker for human prostate cancer. Clin Cancer Res 12: 2061-2065, 2006.

73. Sim EU, Ang CH, Ng CC, Lee CW and Narayanan K: Differential expression of a subset of ribosomal protein genes in cell lines derived from human nasopharyngeal epithelium. J Hum Genet 55: 118-120, 2010.

74. Yong WH, Shabihkhani M, Telesca D, Yang S, Tso JL, Menjivar JC, Wei B, Lucey GM, Mareninov S, Chen Z, et al: Ribosomal proteins RPS11 and RPS20, two stress-response markers of glioblastoma stem cells, are novel predictors of poor prognosis in glioblastoma patients. PLoS One 10: e0141334, 2015.

75. Yan TT, Fu XL, Li J, Bian YN, Liu DJ, Hua R, Ren LL, Li CT, Sun YW, Chen HY, et al: Downregulation of RPL15 may predict poor survival and associate with tumor progression in pancreatic ductal adenocarcinoma. Oncotarget 6: 37028-37042, 2015.

76. Kobayashi T, Sasaki Y, Oshima Y, Yamamoto H, Mita H, Suzuki H, Toyota M, Tokino T, Itoh F, Imai K, et al: Activation of the ribosomal protein L13 gene in human gastrointestinal cancer. Int J Mol Med 18: 161-170, 2006.

77. Song MJ, Jung CK, Park CH, Hur W, Choi JE, Bae SH, Choi JY, Choi SW, Han NI and Yoon SK: RPL36 as a prognostic marker in hepatocellular carcinoma. Pathol Int 61: 638-644, 2011.

78. de Las Heras-Rubio A, Perucho L, Paciucci R, Vilardell J and LLeonart ME: Ribosomal proteins as novel players in tumorigenesis. Cancer Metastasis Rev 33: 115-141, 2014.

79. De Keersmaecker K, Sulima SO and Dinman JD: Ribosomopathies and the paradox of cellular hypo- to hyperproliferation. Blood 125: 1377-1382, 2015.

80. Ruggero D and Pandolfi PP: Does the ribosome translate cancer? Nat Rev Cancer 3: 179-192, 2003.

81. Warner JR and McIntosh KB: How common are extraribosomal functions of ribosomal proteins? Mol Cell 34: 3-11, 2009.
82. Barkić M, Crnomarković S, Grabusić K, Bogetić I, Panić L, Tamarut S, Cokarić M, Jerić I, Vidak S and Volarević S: The p53 tumor suppressor causes congenital malformations in Rpl24deficient mice and promotes their survival. Mol Cell Biol 29: 2489-2504, 2009.

83. Kondrashov N, Pusic A, Stumpf CR, Shimizu K, Hsieh AC, Xue S, Ishijima J, Shiroishi T and Barna M: Ribosome-mediated specificity in Hox mRNA translation and vertebrate tissue patterning. Cell 145: 383-397, 2011.

84. Holmberg Olausson K, Nistér $M$ and Lindström MS: p53-dependent and -independent nucleolar stress responses. Cells 1: 774-798, 2012.

85. James A, Wang Y, Raje H, Rosby R and DiMario P: Nucleolar stress with and without p53. Nucleus 5: 402-426, 2014.

86. Panić L, Tamarut S, Sticker-Jantscheff M, Barkić M, Solter D, Uzelac M, Grabusić K and Volarević S: Ribosomal protein S6 gene haploinsufficiency is associated with activation of a p53-dependent checkpoint during gastrulation. Mol Cell Biol 26: 8880-8891, 2006.

87. McGowan KA, Li JZ, Park CY, Beaudry V, Tabor HK, Sabnis AJ, Zhang W, Fuchs H, de Angelis MH, Myers RM, et al: Ribosomal mutations cause p53-mediated dark skin and pleiotropic effects. Nat Genet 40: 963-970, 2008.

88. Anderson SJ, Lauritsen JP, Hartman MG, Foushee AM, Lefebvre JM, Shinton SA, Gerhardt B, Hardy RR, Oravecz T and Wiest DL: Ablation of ribosomal protein L22 selectively impairs alphabeta $\mathrm{T}$ cell development by activation of a $\mathrm{p} 53$-dependent checkpoint. Immunity 26: 759-772, 2007.

89. Barlow JL, Drynan LF, Hewett DR, Holmes LR, LorenzoAbalde S, Lane AL, Jolin HE, Pannell R, Middleton AJ, Wong SH, et al: A p53-dependent mechanism underlies macrocytic anemia in a mouse model of human 5q- syndrome. Nat Med 16: 59-66, 2010.

90. Terzian T and Box N: Genetics of ribosomal proteins: "curiouser and curiouser'. PLoS Genet 9: e1003300, 2013.

91.Fumagalli S, Di Cara A, Neb-Gulati A, Natt F, Schwemberger S, Hall J, Babcock GF, Bernardi R, Pandolfi PP and Thomas G: Absence of nucleolar disruption after impairment of $40 \mathrm{~S}$ ribosome biogenesis reveals an rpL11-translation-dependent mechanism of p53 induction. Nat Cell Biol 11: 501-508, 2009.

92. Volarevic S, Stewart MJ, Ledermann B, Zilberman F, Terracciano L, Montini E, Grompe M, Kozma SC and Thomas G: Proliferation, but not growth, blocked by conditional deletion of 40S ribosomal protein S6. Science 288: 2045-2047, 2000.

93. Jaako P, Flygare J, Olsson K, Quere R, Ehinger M, Henson A, Ellis S, Schambach A, Baum C, Richter J, et al: Mice with ribosomal protein $\mathrm{S} 19$ deficiency develop bone marrow failure and symptoms like patients with Diamond-Blackfan anemia. Blood 118: 6087-6096, 2011.

94.Fumagalli S, Ivanenkov VV, Teng T and Thomas G: Suprainduction of p53 by disruption of $40 \mathrm{~S}$ and $60 \mathrm{~S}$ ribosome biogenesis leads to the activation of a novel G2/M checkpoint. Genes Dev 26: 1028-1040, 2012.

95. Teng T, Mercer CA, Hexley P, Thomas G and Fumagalli S: Loss of tumor suppressor RPL5/RPL11 does not induce cell cycle arrest but impedes proliferation due to reduced ribosome content and translation capacity. Mol Cell Biol 33: 4660-4671, 2013.

96. Donati G, Peddigari S, Mercer CA and Thomas G: 5S ribosomal RNA is an essential component of a nascent ribosomal precursor complex that regulates the Hdm2-p53 checkpoint. Cell Rep 4: 87-98, 2013.

97. Sloan KE, Bohnsack MT and Watkins NJ: The 5S RNP couples p53 homeostasis to ribosome biogenesis and nucleolar stress. Cell Rep 5: 237-247, 2013.

98. Macias E, Jin A, Deisenroth C, Bhat K, Mao H, Lindström MS and Zhang Y: An ARF-independent c-MYC-activated tumor suppression pathway mediated by ribosomal protein-Mdm2 Interaction. Cancer Cell 18: 231-243, 2010.

99. Deisenroth $C$ and Zhang Y: Ribosome biogenesis surveillance: Probing the ribosomal protein-Mdm2-p53 pathway. Oncogene 29: 4253-4260, 2010.

100. Miliani de Marval PL and Zhang Y: The RP-Mdm2-p53 pathway and tumorigenesis. Oncotarget 2: 234-238, 2011.

101.Zhang Y and Lu H: Signaling to p53: Ribosomal proteins find their way. Cancer Cell 16: 369-377, 2009.

102. Nishimura K, Kumazawa T, Kuroda T, Katagiri N, Tsuchiya M, Goto N, Furumai R, Murayama A, Yanagisawa J and Kimura K: Perturbation of ribosome biogenesis drives cells into senescence through 5S RNP-mediated p53 activation. Cell Rep 10: 1310$1323,2015$. 
103. Liu Y, He Y, Jin A, Tikunov AP, Zhou L, Tollini LA, Leslie P, Kim TH, Li LO, Coleman RA, et al: Ribosomal protein-Mdm2p53 pathway coordinates nutrient stress with lipid metabolism by regulating MCD and promoting fatty acid oxidation. Proc Natl Acad Sci USA 111: E2414-E2422, 2014.

104. Meng X, Carlson NR, Dong J and Zhang Y: Oncogenic c-Mycinduced lymphomagenesis is inhibited non-redundantly by the p19Arf-Mdm2-p53 and RP-Mdm2-p53 pathways. Oncogene 34: $5709-5717,2015$.

105. Jaako P, Debnath S, Olsson K, Zhang Y, Flygare J,Lindström MS, Bryder D and Karlsson S: Disruption of the 5S RNP-Mdm2 interaction significantly improves the erythroid defect in a mouse model for Diamond-Blackfan anemia. Leukemia 29: 2221-2229, 2015

106.Lindström MS, Deisenroth C and Zhang Y: Putting a finger on growth surveillance: Insight into MDM2 zinc finger-ribosomal protein interactions. Cell Cycle 6: 434-437, 2007.

107. Lindström MS, Jin A, Deisenroth C, White Wolf G and Zhang Y: Cancer-associated mutations in the MDM2 zinc finger domain disrupt ribosomal protein interaction and attenuate MDM2 induced p53 degradation. Mol Cell Biol 27: 1056-1068, 2007.

108.109. Zhang Q, Xiao H, Chai SC, Hoang QQ and Lu H: Hydrophilic residues are crucial for ribosomal protein L11 (RPL11) interaction with zinc finger domain of MDM2 and p53 protein activation. J Biol Chem 286: 38264-38274, 2011.

109. Danilova N, Sakamoto KM and Lin S: Ribosomal protein S19 deficiency in zebrafish leads to developmental abnormalities and defective erythropoiesis through activation of $\mathrm{p} 53$ protein family. Blood 112: 5228-5237, 2008.

110. Torihara H, Uechi T, Chakraborty A, Shinya M, Sakai N and Kenmochi N: Erythropoiesis failure due to RPS19 deficiency is independent of an activated Tp53 response in a zebrafish model of Diamond-Blackfan anaemia. Br J Haematol 152: 648-654, 2011

111. Uechi T, Nakajima Y, Chakraborty A, Torihara H, Higa S and Kenmochi N: Deficiency of ribosomal protein S19 during early embryogenesis leads to reduction of erythrocytes in a zebrafish model of Diamond-Blackfan anemia. Hum Mol Genet 17: 3204-3211, 2008

112. Uechi T, Nakajima Y, Nakao A, Torihara H, Chakraborty A, Inoue $\mathrm{K}$ and Kenmochi N: Ribosomal protein gene knockdown causes developmental defects in zebrafish. PLoS One 1: e37, 2006

113. Yadav GV, Chakraborty A, Uechi $\mathrm{T}$ and Kenmochi $\mathrm{N}$ Ribosomal protein deficiency causes Tp53-independent erythropoiesis failure in zebrafish. Int J Biochem Cell Biol 49: 1-7, 2014

114. Jädersten M, Saft L, Smith A, Kulasekararaj A, Pomplun S Göhring G, Hedlund A, Hast R, Schlegelberger B, Porwit A, et al: TP53 mutations in low-risk myelodysplastic syndromes with del $(5 q)$ predict disease progression. J Clin Oncol 29 1971-1979, 2011.

115. Saft L, Karimi M, Ghaderi M, Matolcsy A, Mufti GJ, Kulasekararaj A, Göhring G, Giagounidis A, Selleslag D, Muus $\mathrm{P}$, et al: p53 protein expression independently predicts outcome in patients with lower-risk myelodysplastic syndromes with del(5q). Haematologica 99: 1041-1049, 2014.

116. Antunes AT, Goos YJ, Pereboom TC, Hermkens D Wlodarski MW, Da Costa L and MacInnes AW: Ribosomal Protein mutations result in constitutive p53 protein degradation through impairment of the AKT pathway. PLoS Genet 11: e1005326, 2015

117. Heijnen HF, van Wijk R, Pereboom TC, Goos YJ, Seinen CW, van Oirschot BA, van Dooren R, Gastou M, Giles RH, van Solinge $\mathrm{W}$, et al: Ribosomal protein mutations induce autophagy through S6 kinase inhibition of the insulin pathway. PLoS Genet 10: e1004371, 2014.

118. Zheng J, Lang Y, Zhang Q, Cui D, Sun H, Jiang L, Chen Z, Zhang R, Gao Y, Tian W, et al: Structure of human MDM2 complexed with RPL11 reveals the molecular basis of p53 activation. Genes Dev 29: 1524-1534, 2015.

119. Ma $\mathrm{H}$ and Pederson T: The nucleolus stress response is coupled to an ATR-Chk1-mediated G2 arrest. Mol Biol Cell 24: $1334-1342,2013$

120. Danilova N, Bibikova E, Covey TM, Nathanson D, Dimitrova E, Konto Y, Lindgren A, Glader B, Radu CG, Sakamoto KM, et al: The role of the DNA damage response in zebrafish and cellular models of Diamond Blackfan anemia. Dis Model Mech 7: 895-905, 2014

121.Padeken J and Heun P: Nucleolus and nuclear periphery: Velcro for heterochromatin. Curr Opin Cell Biol 28: 54-60, 2014
122. O'Donohue MF, Choesmel V, Faubladier M, Fichant G and Gleizes PE: Functional dichotomy of ribosomal proteins during the synthesis of mammalian 40S ribosomal subunits. J Cell Biol 190: 853-866, 2010

123.Peng JC and Karpen GH: H3K9 methylation and RNA interference regulate nucleolar organization and repeated DNA stability. Nat Cell Biol 9: 25-35, 2007.

124. Boglev Y, Badrock AP, Trotter AJ, Du Q, Richardson EJ, Parslow AC, Markmiller SJ, Hall NE, de Jong-Curtain TA, $\mathrm{Ng}$ AY, et al: Autophagy induction is a Tor- and Tp53independent cell survival response in a zebrafish model of disrupted ribosome biogenesis. PLoS Genet 9: e1003279, 2013.

125. Donati G, Brighenti E, Vici M, Mazzini G, Treré D, Montanaro L and Derenzini M: Selective inhibition of rRNA transcription downregulates E2F-1: A new p53-independent mechanism linking cell growth to cell proliferation. J Cell Sci 124: 3017-3028, 2011

126. Donati G, Montanaro L and Derenzini M: Ribosome biogenesis and control of cell proliferation: p53 is not alone. Cancer Res 72: 1602-1607, 2012.

127. Orsolic I, Jurada D, Pullen N, Oren M, Eliopoulos AG and Volarevic S: The relationship between the nucleolus and cancer: Current evidence and emerging paradigms. Semin Cancer Biol Dec 23, 2015 (Epub ahead of print).

128. Marcel V, Ghayad SE, Belin S, Therizols G, Morel AP, SolanoGonzàlez E, Vendrell JA, Hacot S, Mertani HC, Albaret MA, et al: 553 acts as a safeguard of translational control by regulating fibrillarin and rRNA methylation in cancer. Cancer Cell 24: 318-330, 2013

129. Sulima SO, Patchett S, Advani VM, De Keersmaecker K, Johnson AW and Dinman JD: Bypass of the pre-60S ribosomal quality control as a pathway to oncogenesis. Proc Natl Acad Sci USA 111: 5640-5645, 2014.

130.Ludwig LS, Gazda HT, Eng JC, Eichhorn SW, Thiru P, Ghazvinian R, George TI, Gotlib JR, Beggs AH, Sieff CA, et al: Altered translation of GATA1 in Diamond-Blackfan anemia. Nat Med 20: 748-753, 2014.

131. Sankaran VG, Ghazvinian R, Do R, Thiru P, Vergilio JA, Beggs AH, Sieff CA, Orkin SH, Nathan DG, Lander ES, et al: Exome sequencing identifies GATA1 mutations resulting in Diamond-Blackfan anemia. J Clin Invest 122: 2439-2443, 2012.

132. Amanatiadou EP, Papadopoulos GL, Strouboulis J and Vizirianakis IS: GATA1 and PU.1 bind to ribosomal protein genes in erythroid cells: Implications for ribosomopathies. PLoS One 10: e0140077, 2015.

133.Loreni F, Mancino M and Biffo S: Translation factors and ribosomal proteins control tumor onset and progression: How? Oncogene 33: 2145-2156, 2014.

134. Ingolia NT: Ribosome profiling: New views of translation, from single codons to genome scale. Nat Rev Genet 15: 205-213, 2014.

135. Bhavsar RB, Makley LN and Tsonis PA: The other lives of ribosomal proteins. Hum Genomics 4: 327-344, 2010.

136. Lindström MS: Emerging functions of ribosomal proteins in gene-specific transcription and translation. Biochem Biophys Res Commun 379: 167-170, 2009.

137. Wool IG: Extraribosomal functions of ribosomal proteins. Trends Biochem Sci 21: 164-165, 1996.

138. Naora H, Takai I, Adachi M and Naora H: Altered cellular responses by varying expression of a ribosomal protein gene: Sequential coordination of enhancement and suppression of ribosomal protein S3a gene expression induces apoptosis. J Cell Biol 141: 741-753, 1998

139. Guo X, Shi Y, Gou Y, Li J, Han S, Zhang Y, Huo J, Ning X, Sun L, Chen Y, et al: Human ribosomal protein S13 promotes gastric cancer growth through down-regulating p27(Kip1). J Cell Mol Med 15: 296-306, 2011.

140. Shi Y, Zhai H, Wang X, Han Z, Liu C, Lan M, Du J, Guo C, Zhang Y, Wu K, et al: Ribosomal proteins S13 and L23 promote multidrug resistance in gastric cancer cells by suppressing druginduced apoptosis. Exp Cell Res 296: 337-346, 2004

141. Dai MS and Lu H: Inhibition of MDM2-mediated p53 ubiquitination and degradation by ribosomal protein L5. J Biol Chem 279: 44475-44482, 2004

142. Daftuar L, Zhu Y, Jacq X and Prives C: Ribosomal proteins RPL37, RPS15 and RPS20 regulate the Mdm2-p53-MdmX network. PLoS One 8: e68667, 2013.

143. Wang S, Huang J, He J, Wang A, Xu S, Huang SF and Xiao S: RPL41, a small ribosomal peptide deregulated in tumors, is essential for mitosis and centrosome integrity. Neoplasia 12: 284-293, 2010 
144.Krüger T, Zentgraf $\mathrm{H}$ and Scheer U: Intranucleolar sites of ribosome biogenesis defined by the localization of early binding ribosomal proteins. J Cell Biol 177: 573-578, 2007.

145. Chan YL, Diaz JJ, Denoroy L, Madjar JJ and Wool IG: The primary structure of rat ribosomal protein L10: Relationship to a Jun-binding protein and to a putative Wilms' tumor suppressor. Biochem Biophys Res Commun 225: 952-956, 1996.

146. Houmani JL, Davis CI and Ruf IK: Growth-promoting properties of Epstein-Barr virus EBER-1 RNA correlate with ribosomal protein L22 binding. J Virol 83: 9844-9853, 2009.

147.Ni JQ, Liu LP, Hess D, Rietdorf J and Sun FL: Drosophila ribosomal proteins are associated with linker histone $\mathrm{H} 1$ and suppress gene transcription. Genes Dev 20: 1959-1973, 2006.

148. Fahl SP, Harris B, Coffey F and Wiest DL: Rpl22 Loss impairs the development of $\mathrm{B}$ lymphocytes by activating a p53-dependent checkpoint. J Immunol 194: 200-209, 2015.

149. Rashkovan M, Vadnais C, Ross J, Gigoux M, Suh WK, Gu W, Kosan C and Möröy T: Miz-1 regulates translation of Trp53 via ribosomal protein L22 in cells undergoing V(D)J recombination. Proc Natl Acad Sci USA 111: E5411-E5419, 2014.

150. Montanaro L, Treré D and Derenzini M: Nucleolus, ribosomes, and cancer. Am J Pathol 173: 301-310, 2008.

151. Treré D, Ceccarelli C, Montanaro L, Tosti E and Derenzini M: Nucleolar size and activity are related to pRb and p53 status in human breast cancer. J Histochem Cytochem 52: 1601-1607, 2004.

152. Montanaro L, Treré D and Derenzini M: The emerging role of RNA polymerase I transcription machinery in human malignancy: A clinical perspective. Onco Targets Ther 6: 909-916, 2013.

153. Drygin D, O'Brien SE, Hannan RD, McArthur GA and Von Hoff DD: Targeting the nucleolus for cancer-specific activation of p53. Drug Discov Today 19: 259-265, 2014.

154.Drygin D, Siddiqui-Jain A, O'Brien S, Schwaebe M, Lin A, Bliesath J, Ho CB, Proffitt C, Trent K, Whitten JP, et al: Anticancer activity of CX-3543: A direct inhibitor of rRNA biogenesis. Cancer Res 69: 7653-7661, 2009.
155. Drygin D, Lin A, Bliesath J, Ho CB, O'Brien SE, Proffitt C, Omori M, Haddach M, Schwaebe MK, Siddiqui-Jain A, et al: Targeting RNA polymerase I with an oral small molecule CX-5461 inhibits ribosomal RNA synthesis and solid tumor growth. Cancer Res 71: 1418-1430, 2011.

156. Bywater MJ, Poortinga G, Sanij E, Hein N, Peck A, Cullinane C, Wall M, Cluse L, Drygin D, Anderes K, et al: Inhibition of RNA polymerase I as a therapeutic strategy to promote cancer-specific activation of p53. Cancer Cell 22: 51-65, 2012.

157. Peltonen K, Colis L, Liu H, Trivedi R, Moubarek MS Moore HM, Bai B, Rudek MA, Bieberich CJ and Laiho M: A targeting modality for destruction of RNA polymerase I that possesses anticancer activity. Cancer Cell 25: 77-90, 2014

158. Colis L, Peltonen K, Sirajuddin P, Liu H, Sanders S, Ernst G, Barrow JC and Laiho M: DNA intercalator BMH-21 inhibits RNA polymerase I independent of DNA damage response. Oncotarget 5: 4361-4369, 2014.

159. Morgado-Palacin L, Llanos S, Urbano-Cuadrado M, BlancoAparicio C, Megias D, Pastor J and Serrano M: Non-genotoxic activation of p53 through the RPL11-dependent ribosomal stress pathway. Carcinogenesis 35: 2822-2830, 2014.

160. Wang M, Hu Y and Stearns ME: RPS2: a novel therapeutic target in prostate cancer. J Exp Clin Cancer Res 28: 6, 2009.

161. Bee A, Brewer D, Beesley C, Dodson A, Forootan S, Dickinson T, Gerard P, Lane B, Yao S, Cooper CS, et al: siRNA knockdown of ribosomal protein gene RPL19 abrogates the aggressive phenotype of human prostate cancer. PLoS One 6: e22672, 2011.

162. Marcel V, Catez F and Diaz JJ: Ribosomes: The future of targeted therapies? Oncotarget 4: 1554-1555, 2013.

163. Wu G, Broniscer A, McEachron TA, Lu C, Paugh BS, Becksfort J, Qu C, Ding L, Huether R, Parker M, et al; St. Jude Children's Research Hospital-Washington University Pediatric Cancer Genome Project: Somatic histone H3 alterations in pediatric diffuse intrinsic pontine gliomas and non-brainstem glioblastomas. Nat Genet 44: 251-253, 2012. 